\title{
СЕЛЕКЦІЯ, ДЕНДРОЛОГІЯ
}

УДК: 630.165 .6

https://doi.org/10.33220/1026-3365.136.2020.46

\author{
С. А. ЛОСЬ ${ }^{1}$, В. П. САМОДАЙ ${ }^{2}$, Л. І. ТЕРЕЩЕНКО \\ СУЧАСНИЙ СТАН БУКА В ДОСЛІДНИХ КУЛЬТУРАХ І ДЕНДРОПАРКАХ \\ ПІВНІЧНОГО СХОДУ УКРАЇНИ ТА ПЕРСПЕКТИВИ ЙОГО ВИКОРИСТАННЯ \\ ${ }^{1}$ Украйнський науково-дослідний інститут лісового господарства і агролісомеліорачії ім. Г. М. Височького \\ ${ }^{2}$ Краснотростянеиьке відділення Українського науково-дослідного інституту лісового господарства $i$ \\ агролісомеліорації ім. Г. М. Висоцького \\ ${ }^{3}$ Харківська державна зооветеринарна академія
}

\begin{abstract}
Представлено узагальнені результати обстеження насаджень бука лісового (Fagus sylvatica L.), бука східного (Fagus orientalis Lypsky.) та бука кримського (Fagus taurica Popl.) у дослідних культурах і дендрологічних парках північного сходу України. Метою досліджень було визначення придатності видів для створення насаджень різного цільового призначення в регіоні. Оцінено 11 насаджень бука за комплексом показників, зокрема за особливостями росту, якістю стовбурів, станом і репродукційним розвитком. За результатами комплексного оцінювання буки лісовий і кримський визнано перспективними для створення плантаційних культур. Буки лісовий, східний і кримський доцільно використовувати також для озеленення в Харківській $\mathrm{i}$ Сумській областях.

Ключові слова: Fagus, комплексне оцінювання, багатостовбурність, селекційна категорія, репродукція.
\end{abstract}

Вступ. Види роду бук Fagus представлені деревами першої величини, які формують перший ярус деревостанів та $\epsilon$ лісоутворювальними. Рід налічує до 10 видів, які розповсюджені в північній півкулі (Zaiachuk 2014 ).

В Україні природно ростуть два види бука - бук лісовий, європейський, або звичайний (Fagus sylvatica L.) і бук кримський (Fagus taurica Popl.), який деякі дослідники вважають підвидом бука східного (Kokhno \& Parkhomenko 2002). Природний ареал першого 3 них приурочений до Карпатських гір, де він має надзвичайно велике екологічне та промислове значення. Букові праліси Карпат у 2017 р. отримали статус об'єкта Всесвітньої природної спадщини ЮНЕСКО «Букові праліси і давні ліси Карпат та інших регіонів Європи» (Stoyko 2018, Prots et al. 2019).

Бук кримський, виокремлений Г. І. Поплавською в самостійний вид, вважається проміжною формою між східним та європейським (Poplavskaya 1927). Цей вид природно росте на території Кримських гір. Бук східний (Fagus orientalis Lypsky.) розповсюджений на Кавказі, у північній частині Ірану, а також на півночі Туреччини та у східній частині Балканського півострова (Molotkov 1966, Zaiachuk 2014). С. М. Стойко (Stoyko 2018) вважає, що основні причини обмеженого поширення природних букових лісів - посилення континентальності клімату із заходу на схід, недостатня кількість опадів, низька температура в зимовий період. Водночас, за дослідженнями лісових культур бука поза межами природного ареалу, проведеними О. М. Корінько (Korinko 2007), він $є$ зимо- та морозостійким, витримує короткочасне зниження температури до $-30 \ldots-35^{\circ} \mathrm{C}$, а також $\epsilon$ посухостійким.

Крона бука добре піддається формуванню, тому його широко застосовують у парковому будівництві для створення живоплотів.

Поза межами природного ареалу бук ще у XIX столітті почали вирощувати в парках. За даними В. Г. Козлова (Kozlov 1992), в Україні культивують 3 види і 15 декоративних форм бука. Крім бука лісового в ботанічних садах, дендропарках і старовинних ландшафтних парках представлені буки східний та американський, а також декоративні форми бука лісового (Kozlov 1992, Rumiankov 2018).

Бук лісовий за межами природного ареалу використовують для створення лісових культур, переважно в західних областях України. На Правобережжі він формує високопродуктивні деревостани (Belous 1962, Kokhno \& Parkhomenko 2002, Korinko 2007). Незважаючи на те, що лівобережна частина України вирізняється більш континентальним 


\section{ЛICIВНИЦТВО I АГРОЛІСОМЕЛІОРАЦIЯ - FORESTRY AND FOREST МЕLIORATION}

2020. Вй. 136 - 2020. Iss. 136

кліматом, ніж природний ареал, результати інтродукції бука лісового та кримського у більшості випадків були позитивними (Ihnatenko et al. 2006, Los et al. 2014). За даними попередніх досліджень бук лісовий i кримський в умовах північного Лівобережного Лісостепу переважно мають високі адаптаційні властивості та вирізняються високими кількісними й якісними показниками (Los et al. 2014, 2018). Отже, інтродукцію цих видів слід вважати порівняно успішною.

Метою роботи було визначення перспективності видів роду Fagus для створення на північному сході України насаджень різного цільового призначення на основі комплексного оцінювання росту та розвитку видів у дослідних культурах і дендропарках.

Матеріали й методи. У статті наведено узагальнені результати досліджень бука в дендрологічних парках і географічних культурах північного сходу України. Дослідження проведені впродовж останніх років згідно 3 доопрацьованою методикою комплексного оцінювання перспективності інтродукованих видів.

Об’єктами досліджень були дослідні культури й насадження бука лісового та кримського в дендропарках Сумської та Харківської областей, переважно в умовах свіжої діброви $\left(\mathrm{D}_{2}\right)$, на темно-сірих лісових грунтах суглинистого механічного складу. Лише одна ділянка (дендропарк ДП «Балаклійське ЛГ») розташована в умовах $\mathrm{C}_{2}$ (табл. 1, рис. 1).

Характеристика обстежених насаджень бука

Таблиияя 1

\begin{tabular}{|c|c|c|c|c|c|}
\hline $\begin{array}{c}\text { № } \\
\text { пробної } \\
\text { площі } \\
\text { (ПП) }\end{array}$ & Видова назва & Походження насіння & ТЛУ & $\begin{array}{c}\text { Вік на час } \\
\text { обстеження, } \\
\text { років }\end{array}$ & $\begin{array}{c}\text { Площа } \\
\text { або } \\
\text { кількість } \\
\text { рослин, } \\
\text { екз. }\end{array}$ \\
\hline \multicolumn{6}{|c|}{ Сумська область, ДП «Тростянецьке ЛГ», дослідні культури } \\
\hline 1 & Fagus sylvatica $\mathrm{L}$. & Мукачівський ЛК ${ }^{1}$ & $\mathrm{D}_{2}$ & $56(2018)$ & 1,3 га \\
\hline \multicolumn{6}{|c|}{ Сумська область, ДП «Тростянецьке ЛГ», дендропарк } \\
\hline 2 & Fagus sylvatica $\mathrm{L}$. & Мукачівський ЛК & $\mathrm{D}_{2}$ & 55 (2017) & \multirow[t]{2}{*}{0,2 га } \\
\hline 3 & Fagus taurica Popl. & АР Крим & $\mathrm{D}_{2}$ & $55(2017)$ & \\
\hline \multicolumn{6}{|c|}{ Харківська область, ДП «Харківська ЛНДС²», Південне л-во, географічні культури } \\
\hline 4 & Fagus sylvatica $\mathrm{L}$. & Мукачівський ЛК, г. Гостра & $\mathrm{D}_{2}$ & 48 (2019) & 0,15 га \\
\hline 5 & Fagus sylvatica $\mathrm{L}$. & Мукачівський ЛК, ур. Щирець & $\mathrm{D}_{2}$ & 48 (2019) & 0,25 га \\
\hline 6 & Fagus sylvatica $\mathrm{L}$. & Мукачівський ЛК, ур. Березинка & $\mathrm{D}_{2}$ & $48(2019)$ & 0,20 га \\
\hline \multicolumn{6}{|c|}{ Харківська область, ДП «Харківська ЛНДС», Південне л-во, дендропарк УкрНДІЛГА } \\
\hline 7 & Fagus sylvatica $\mathrm{L}$. & Мукачівський ЛК & $\mathrm{D}_{2}$ & $40(2019)$ & 5 екз. \\
\hline 8 & Fagus taurica Popl. & АР Крим & $\mathrm{D}_{2}$ & 40 (2019) & 15 екз. \\
\hline \multicolumn{6}{|c|}{ Харківська область, дендропарк ХНАУ } \\
\hline 9 & Fagus sylvatica $\mathrm{L}$. & НЛТУ $^{4}$, Львів & $\mathrm{D}_{2}$ & $50(2019)$ & 19 екз. \\
\hline 10 & Fagus orientalis Lypsky. & Ставропільський ботанічний сад & $\mathrm{D}_{2}$ & $50(2019)$ & 5 екз. \\
\hline \multicolumn{6}{|c|}{ Харківська область, дендропарк ДП «Балаклійське ЛГ» } \\
\hline 11 & Fagus sylvatica $\mathrm{L}$. & невідоме & $\mathrm{C}_{2}$ & 58 (2019) & 4 екз. \\
\hline
\end{tabular}

Примітка: Мукачівський ЛК ${ }^{1}-$ Мукачівський лісокомбінат; ДП «Харківська ЛНДС» ${ }^{2}-$ державне підприємство «Харківська лісова науково-дослідна станція» Українського науково-дослідного інституту лісового господарства та агролісомеліорації імені Г. М. Висоцького (УкрНДІЛГА); ХНАУ ${ }^{3}-$ Харківський національний аграрний університет ім. В. В. Докучаєва, НЛТУ ${ }^{4}-$ Національний лісотехничний університет України.

Дослідні мішані дубово-букові культури в ДП «Тростянецьке ЛГ» створені в 1964 р. Ряди бука лісового чергуються з рядами дуба звичайного (Quercus robur L.) i бука лісового за схемою садіння 2,0 × 0,7 м. Насіння бука отримане з Мукачівського лісокомбінату (нині ДП «Мукачівське лісове господарство»), жолуді дуба (контроль) - місцевого збору. 
Приживлюваність сіянців була доволі високою та сягала в середньому 96 \%. Біологічний вік рослин на рік обстеження (2018) становив 58 років.

Географічні культури бука лісового, створені під керівництвом проф. П. І. Молоткова в Південному лісництві ДП «Харківська ЛНДС», представлені деревами трьох походжень: гора Гостра (800-1000 м н. р. м.), урочище Щирець (600-800 м н. р. м.), урочище Березинка (150-200 м н. р. м.) (рис.1).
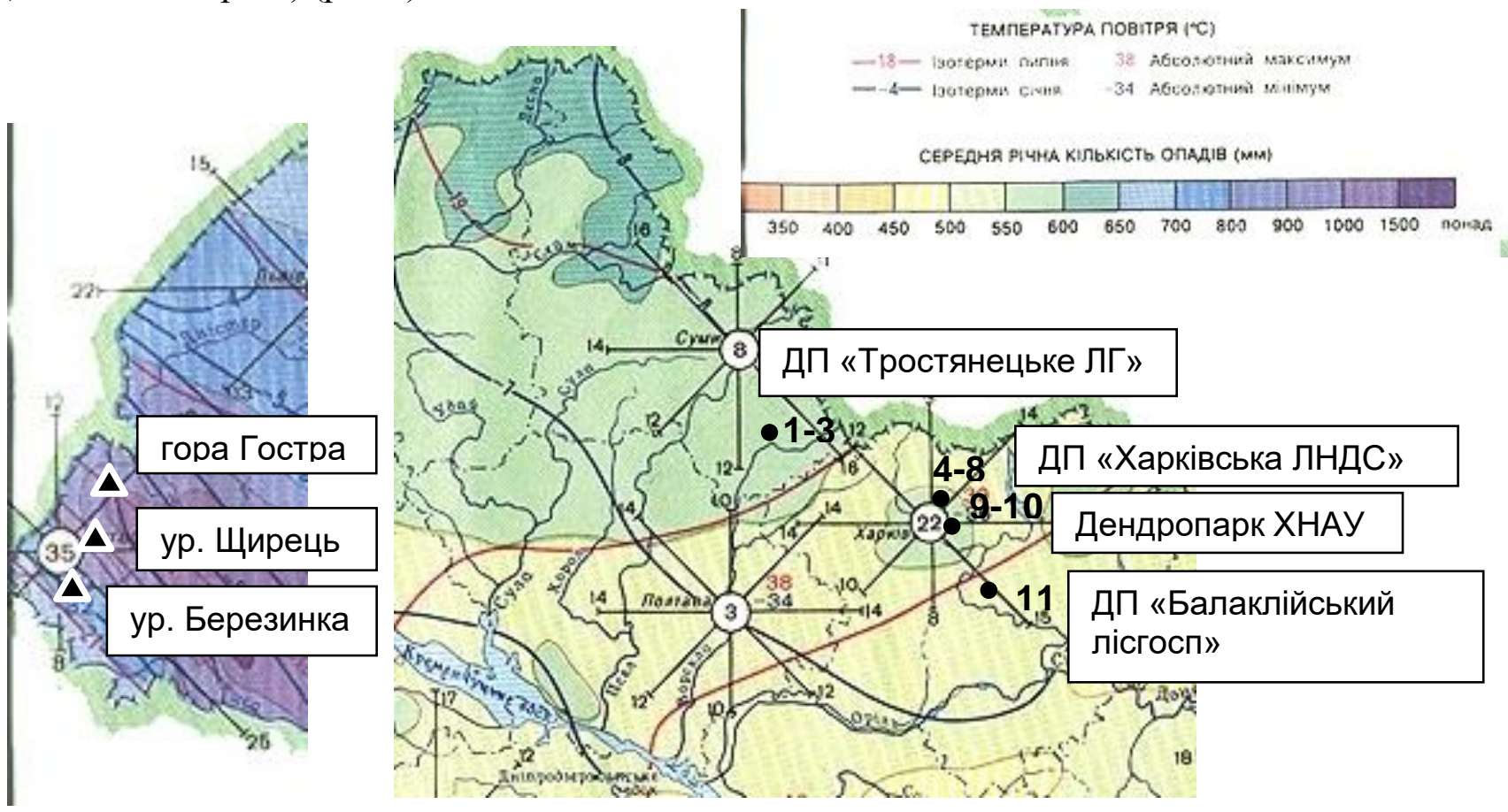

Рис. 1 - Розташування місць заготівлі насіння ( $\triangle$ ) та обстежених об'сктів (•) (нумерація відповідно до таблиці 1)

Однорічні сіянці цих походжень бука завезено до м. Харкова у 1973 р. з Мукачівського лісокомбінату. У попередні роки культури обстежено тричі - у 1978, 1981 та 2013 рр. (Molotkov1986, Los et al. 2014). Культури часто пошкоджували ранньовесняні приморозки та зимові морози, і в 1981 р. збереженість дерев бука була низькою.

Ділянки бука обстежено на території чотирьох дендрологічних парків, а саме: ДП «Тростянецьке ЛГ» Сумської області, УкрНДІЛГА на території ДП «Харківська ЛНДС», ХНАУ та ДП «Балаклійське ЛГ» Харківської області.

У дендропарку ДП «Тростянецьке ЛГ» у 1964 р. висаджено окремо буки лісовий i кримський на ділянках загальною площею 0,2 га. Схема садіння $-4,0 \times 0,7$ м. За даними подальших інвентаризацій колекції у дендропарку збереженість видів бука була високою. Насіння бука лісового отримано з Мукачівського лісокомбінату, а кримського - 3 Криму. Схема садіння - рядами 4,0 × 0,7 м, площа - 0,2 га. На час обстеження (2017 p.) біологічний вік бука становив 55 років.

У дендропарку УкрНДІЛГА буки лісовий і кримський висаджені у 80-ті роки XX століття за ініціативою П. І. Молоткова у південно-східній частині (Molotkov not published).

Куртини буків лісового та східного в дендропарку ХНАУ розташовані поряд, у його центральній частині. Бук лісовий на ділянці висаджений із порядковим змішуванням із грабом звичайним, бук східний - чистою групою (Sytnyk 2017). На час обстеження у 2019 p. біологічний вік бука становив близько 50 років, збереглося 19 дерев. 
Дендрологічний парк у ДП «Балаклійське ЛГ» створений у 1962 р. неподалік від цементного заводу з метою вивчення впливу техногенного забруднення на ріст і розвиток деревних рослин. Попередні дослідження бука стосувалися екологічної пластичності виду (Voron et al. 1996). Бук лісовий представлений 4 екземплярами.

Обстеження проводили відповідно до загальноприйнятих лісотаксаційних (Anuchin 1982) і селекційних методик (Shvidenko et al. 1987, Volosyanchuk et al. 2003). Для кожного дерева визначали: діаметр стовбура на висоті 1,3 м у сантиметрах; висоту в метрах; стан; селекційну категорію (СК); наявність вад і пошкоджень. Стан дерев визначали за шкалою, модифікованою на базі шкал категорій життєздатності дуба та санітарного стану: 1 бал відмінний; 2 бали - добрий; 3 бали - задовільний; 4 бали - незадовільний; 5 балів - дерево загинуло (Volosyanchuk et al. 2003).

Для оцінювання інтенсивності росту як контроль використано табличні показники штучних насаджень дуба звичайного. Для порівняння кліматичних умов регіонів походження та інтродукції побудовано кліматограми Болла-Тейлора (Asadulaev et al. 2013).

Для визначення перспективності видів використано комплексне оцінювання успішності інтродукції бука на основі дослідження інтенсивності росту, стану, якості стовбурів i репродуктивного розвитку за баловими шкалами (табл. 2).

Таблиия 2

Шкала комплексного оцінювання успішності інтродукції видів бука

\begin{tabular}{|c|c|c|c|c|c|c|}
\hline Бали & $\begin{array}{c}\text { Інтенсивність } \\
\text { росту за висотою }\end{array}$ & $\begin{array}{c}\text { Інтенсивність } \\
\text { росту за } \\
\text { діаметром }\end{array}$ & Якість стовбурів & $\begin{array}{l}\text { Стан, } \\
\text { бали }\end{array}$ & $\begin{array}{l}\text { Репродуктив- } \\
\text { ний розвиток }\end{array}$ & $\begin{array}{c}\text { Частка } \\
\text { багато- } \\
\text { стовбурних } \\
\text { дерев, \% }\end{array}$ \\
\hline 1 & $\begin{array}{l}\text { поступаються } \\
\text { контролю на } \\
10,1 \text { \% і більше }\end{array}$ & $\begin{array}{l}\text { поступаються } \\
\text { контролю на } \\
30,1 \text { \% і більше }\end{array}$ & $\begin{array}{l}\text { дерева I та } \\
\text { II селекційних } \\
\text { категорій відсутні }\end{array}$ & $4,5-5,0$ & не цвітуть & $81-100$ \\
\hline 2 & $\begin{array}{l}\text { поступаються } \\
\text { від контролю на } \\
4,0-10,0 \%\end{array}$ & $\begin{array}{l}\text { поступаються } \\
\text { контролю на } \\
10,0-30,0 \%\end{array}$ & $\begin{array}{l}\text { частка дерев I та II } \\
\text { селекційних кате- } \\
\text { горій 1,0-10,0 \% }\end{array}$ & $3,5-4,4$ & $\begin{array}{l}\text { цвітуть, але } \\
\text { насіння не } \\
\text { утворюють }\end{array}$ & $61-80$ \\
\hline 3 & $\begin{array}{l}\text { на рівні } \\
\text { контролю або } \\
\text { різниця до 4,0 \% }\end{array}$ & $\begin{array}{l}\text { на рівні } \\
\text { контролю або } \\
\text { різниця до } \\
10,0 \%\end{array}$ & $\begin{array}{l}\text { частка дерев I та } \\
\text { II селекційних } \\
\text { категорій - } \\
\text { 10,1-15,0 \% }\end{array}$ & $2,5-3,4$ & $\begin{array}{l}\text { утворюють } \\
\text { насіння, але } \\
\text { воно не } \epsilon \\
\text { життєздатним }\end{array}$ & $41-60$ \\
\hline 4 & $\begin{array}{l}\text { перевершують } \\
\text { контроль на 4,1- } \\
10,0 \%\end{array}$ & $\begin{array}{l}\text { перевершують } \\
\text { контроль на } \\
10,1-30,0 \%\end{array}$ & $\begin{array}{l}\text { частка дерев I та } \\
\text { II селекційних } \\
\text { категорій - } \\
15,1-20,0 \%\end{array}$ & $1,5-2,4$ & $\begin{array}{l}\text { утворюють } \\
\text { життєздатне } \\
\text { насіння, але } \\
\text { не дають } \\
\text { самосіву }\end{array}$ & $21-40$ \\
\hline 5 & $\begin{array}{l}\text { перевершують } \\
\text { контроль на } \\
10,1 \% \text { і більше }\end{array}$ & $\begin{array}{l}\text { перевершують } \\
\text { контроль більш } \\
\text { ніж на } 30,1 \%\end{array}$ & $\begin{array}{l}\text { частка дерев I та II } \\
\text { селекційних } \\
\text { категорій - 20,1 \% } \\
\text { і більше }\end{array}$ & $1,0-1,4$ & $\begin{array}{l}\text { утворюють } \\
\text { життєздатне } \\
\text { насіння, } \\
\text { дають самосів }\end{array}$ & $1-20$ \\
\hline
\end{tabular}

Для оцінювання репродуктивного розвитку використано шкалу ступенів акліматизації О. Л. Липи (Lypa 1977). До раніше запропонованої шкали (Grybovich et al. 2018) додано показник ступеня багатостовбурності як показник ступеня морозостійкості та стійкості до інших чинників, які впливають на онтогенез рослин у нових умовах місцезростання. Реакцією цього виду на несприятливі умови довкілля як у маргінальних популяціях, так і в 


\section{ЛIСІВНИЦТВО I АГРОЛІСОМЕЛІОРАЦІЯ - FORESTRY AND FOREST МЕLIORATION}

2020. Вип. 136 - 2020. Iss. 136

умовах інтродукції, $є$ зміна форми росту - утворення декількох стовбурів. Так, Г. І. Поплавська (Poplavskaya 1927) у своїх роботах відзначала низькорослість, кущистість і викривлення стовбурів у букових насадженнях біля верхньої межі поширення лісів. Вона пов'язувала це із впливом несприятливих умов росту. За сумою балів види оцінювали як: малоперспективні (6,0-14,0 бала); порівняно перспективні - придатні для створення захисних насаджень і озеленення (14,1-22,0 бала); перспективні - придатні для створення лісових культур, захисних насаджень та озеленення (22,1-30,0 балів).

Результати та обговорення. Основні показники росту та стану насаджень бука наведено в таблиці 3. Оскільки біологічний вік рослин становив від 40 до 58 років (див. табл. 1), порівнювали відносні показники. На переважній більшості ділянок дерева різних видів бука мали добрий і задовільний стан. Масових пошкоджень комахами та уражень хворобами в культурах і дендропарках не виявлено. Поодинокі дерева бука лісового незадовільного стану виявлені у варіанті географічних культур походженням г. Гостра, у дендропарках УкрНДІЛГА та ХНАУ. На ділянці дослідних дубово-букових культур у ДП «Тростянецьке ЛГ» виявлено близько $7 \%$ дерев бука лісового, що всихають через природну внутрішньовидову конкуренцію. Останнім лісовпорядкуванням на ревізійний період у деревостані заплановано проведення догляду.

Бук лісовий представлений на 6 з 9 дослідних об'єктів. За результатами попередніх досліджень авторів (Los et al. 2018), показники інтенсивності росту бука на об'єктах Харківської та Сумської областей помітно різнилися між собою. Найбільшою інтенсивністю росту відзначалися насадження у ДП «Тростянецьке ЛГ», де середній річний приріст за висотою становив від 0,48 до 0,62 м, а за діаметром - від 0,48 до 0,66 см (табл. 3 ).

Таблиця 3

Характеристика обстежених насаджень буків лісового, кримського та східного

\begin{tabular}{|c|c|c|c|c|c|c|c|c|}
\hline \multirow{3}{*}{$\begin{array}{c}\text { № } \\
\text { ПП* }\end{array}$} & \multirow{3}{*}{ Видова назва } & \multicolumn{5}{|c|}{ Середні } & \multirow{3}{*}{ Стан, бали } & \multirow{3}{*}{$\begin{array}{c}\text { Дерева I та } \\
\text { II селек- } \\
\text { ційних } \\
\text { категорій, } \\
\text { \% }\end{array}$} \\
\hline & & \multirow[b]{2}{*}{$H_{\text {cep }}, \mathrm{M}$} & \multirow{2}{*}{$\begin{array}{c}D_{\text {cep }} \\
\text { cM }\end{array}$} & \multirow[b]{2}{*}{$V_{\text {cep }}, \mathrm{M}^{3}$} & \multicolumn{2}{|c|}{ річний приріст } & & \\
\hline & & & & & за $H$, м & $\begin{array}{c}\text { 3а } D \text {, } \\
\text { см }\end{array}$ & & \\
\hline \multicolumn{9}{|c|}{ Сумська область, ДП «Тростянецьке ЛГ», дослідні культури, дендропарк } \\
\hline 1 & F. sylvatica $\mathrm{L}$. & 26,5 & 28,5 & 0,75 & 0,62 & 0,66 & 2,2 & 10,0 \\
\hline 2 & F. sylvatica $\mathrm{L}$. & 20,7 & 23,5 & 0,38 & 0,48 & 0,55 & 2,5 & 23,1 \\
\hline 3 & F. taurica Popl. & 21,4 & 20,4 & 0,34 & 0,50 & 0,48 & 2,5 & 24,0 \\
\hline \multicolumn{9}{|c|}{$\begin{array}{c}\text { Харківська область, ДП «Харківська ЛНДС», Південне л-во, } \\
\mathrm{D}_{2} \text {, географічні культури, дендропарк }\end{array}$} \\
\hline 4 & F. sylvatica $\mathrm{L}$. & 16,4 & 16,6 & 0,16 & 0,34 & 0,35 & 3,0 & 0,0 \\
\hline 5 & F. sylvatica $\mathrm{L}$. & 17,7 & 22,7 & 0,32 & 0,37 & 0,47 & 2,8 & 0,0 \\
\hline 6 & F. sylvatica $\mathrm{L}$. & 15,9 & 16,4 & 0,15 & 0,33 & 0,34 & 3,0 & 0,0 \\
\hline $4-6$ & Середнє по діляниі & 16,3 & 17,0 & 0,16 & 0,34 & 0,35 & 3,0 & 0,0 \\
\hline 7 & F. sylvatica $\mathrm{L}$. & 19,0 & 13,5 & 0,12 & 0,44 & 0,31 & 3,0 & 0,0 \\
\hline 8 & F. taurica Popl. & 14,3 & 15,6 & 0,13 & 0,33 & 0,36 & 2,3 & 0,0 \\
\hline \multicolumn{9}{|c|}{ Харківська область, дендропарк ХНАУ } \\
\hline 9 & F. sylvatica $\mathrm{L}$. & 14,7 & 20,5 & 0,21 & 0,29 & 0,41 & 2,5 & 5,6 \\
\hline 10 & F. orientalis Lypsky. & 19,8 & 34,9 & 0,81 & 0,40 & 0,70 & 2,0 & 0,0 \\
\hline \multicolumn{9}{|c|}{ Харківська область, дендропарк ДП «Балаклійське ЛГ» } \\
\hline 11 & F. sylvatica $\mathrm{L}$. & 14,9 & 27,2 & 0,24 & 0,35 & 0,63 & 2,8 & 0,0 \\
\hline
\end{tabular}

*Нумерація відповідно до таблиці 1.

Показники досліджуваних насаджень Харківщини вирізнялися гіршим ростом. Порівняння середніх висот і діаметрів кліматипів бука лісового, а також річних приростів за діаметром i висотою в географічних культурах виявило певні переваги варіанта 
походженням із урочища Щирець, яке розташоване на висоті 600-800 м. н. р. м. Якщо порівняти 3 табличними даними дуба звичайного такого ж віку, у більшості випадків бук поступається дубу. Винятком $\epsilon$ кліматип походженням із урочища Щирець, який характеризується більшим середнім діаметром стовбура. Об'єм стовбура середнього дерева (рис. 2.) цього найкращого за інтенсивністю росту кліматипу $\left(0,33 \mathrm{~m}^{3}\right) \epsilon$ вдвічі більшим, ніж інших $\left(0,15-0,16 \mathrm{~m}^{3}\right)$, і майже таким самим, як дуба звичайного $\left(0,34 \mathrm{~m}^{3}\right)$.

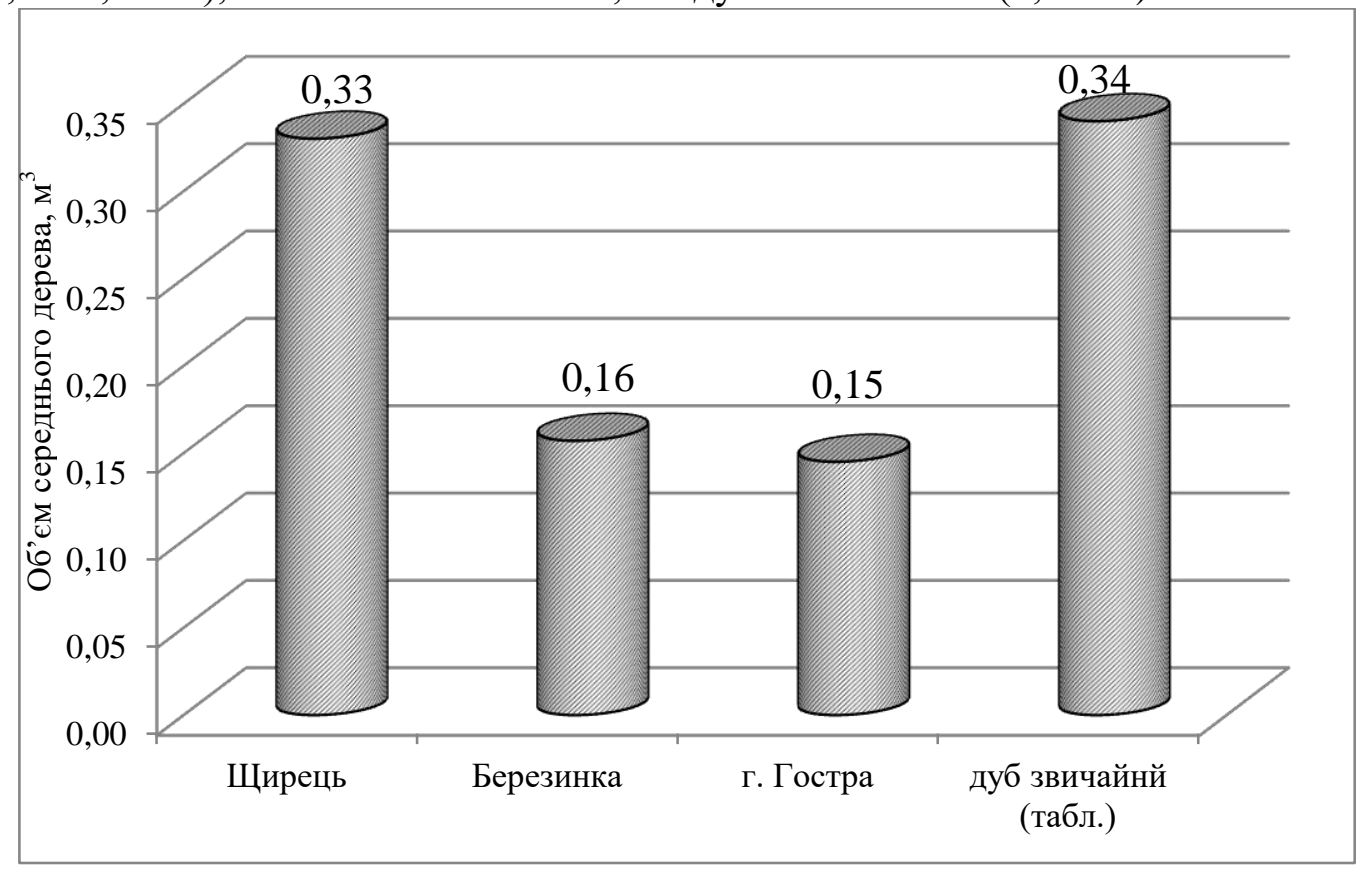

Рис. 2 - Об'см стовбура середнього дерева варіантів у географічних культурах бука лісового (ДП «Харківська ЛНДС»)

Середні річні прирости за висотою становили від 0,33 (г. Гостра) до 0,37 м (ур. Щирець), а за діаметром - від 0,34 до 0,47 см відповідно. Показники дерев бука в дендрологічному парку УкрНДІЛГА варіювали в таких самих межах. Дещо вирізнялися характеристики дерев у дендропарку ХНАУ, де бук лісовий мав ненабагато менший приріст за висотою $(0,29$ см), але приріст за діаметром був близьким до його значень на інших об'єктах Харківської області. Приріст бука лісового в дендрологічному парку ДП «Балаклійське ЛГ» за діаметром був найбільшим серед усіх об’єктів із наявністю цього виду $(0,6$ см).

Порівняння показників росту бука лісового та дуба звичайного місцевого походження, який висаджено як контроль у дослідних культурах ДП «Тростянецьке ЛГ», виявило переваги бука (перевищення за висотою становить 13,5 \%, за діаметром - 6,4 \%). На інших ділянках контроль був відсутній, тому порівняння проводили з табличними показниками насіннєвих дубових деревостанів. Переважання за обома показниками виявлено тільки в дослідних культурах бука лісового у ДП «Тростянецьке ЛГ», лише за діаметром- у насадженнях походженням 3 ур. Щірець, дендропарках ДП «Тростянецьке ЛГ» та ДП «Балаклійське ЛГ» (рис. 3). На решті дослідних об’єктів показники росту бука лісового були меншими за табличні показники дуба звичайного.

Показники інтенсивності росту бука кримського у дендропарках ДП «Тростянецьке ЛГ» та УкрНДІЛГА були подібними до показників бука лісового на зазначених об’єктах. Разом із тим, бук східний у дендропарку ХНАУ, маючи приріст за висотою, близький до показників бука лісового на інших об'єктах Харківської області, вирізнявся найбільшим серед усіх насаджень приростом за діаметром - 0,7 м (див. табл. 3). Порівняння 3 табличними показниками дуба звичайного виявило переваги за висотою бука кримського в дендропарку УкрНДІЛГА і за діаметром - в дендропарку ХНАУ. 


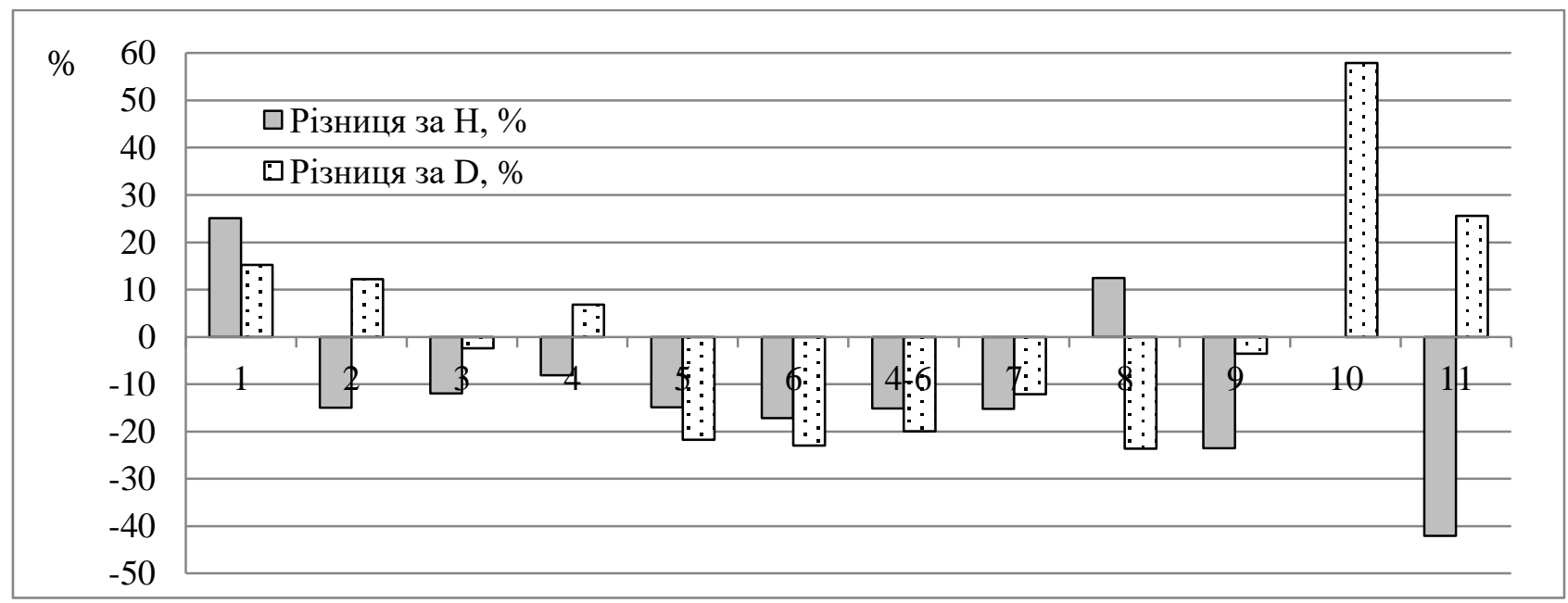

Рис. 3 - Порівняння середніх висот і діаметрів насаджень буків лісового, кримського та східного 3 табличним показниками культур дуба звичайного (нумерація об'єктів відповідно до табл. 1): 1 - бук лісовий (Тростянець, дослідні культури), 2 - бук лісовий (Тростянець, дослідні культури - дендропарк), 3 - бук кримський (Тростянець, дослідні культури - дендропарк), 4-6 - бук лісовий (Харківська ЛНДС, географічні культури), 7 - бук лісовий (Харківська ЛНДС, дендропарк), 8 - бук кримський (Харківська ЛНДС, дендропарк), 9 - бук лісовий (ХНАУ, дендропарк), 10 - бук східний (ХНАУ, дендропарк), 11 - бук лісовий (Балаклея, дендропарк)

Важливим показником під час оцінювання якості стовбурів є селекційна категорія, яка вказує на якість стовбурів дерев. Так само як і за інтенсивністю росту, кращими виявилися насадження у ДП «Тростянецьке ЛГ» (рис. 4). Частка дерев I і II селекційних категорій становила 23,1-24,0 \%. Серед об'єктів, обстежених у Харківській області, найкращою якістю вирізнявся бук лісовий у дендропарку ХНАУ, де відзначено 5,6 \% дерев II селекційної категорії, тоді як на решті об'єктів такі дерева були відсутні (рис. 5).

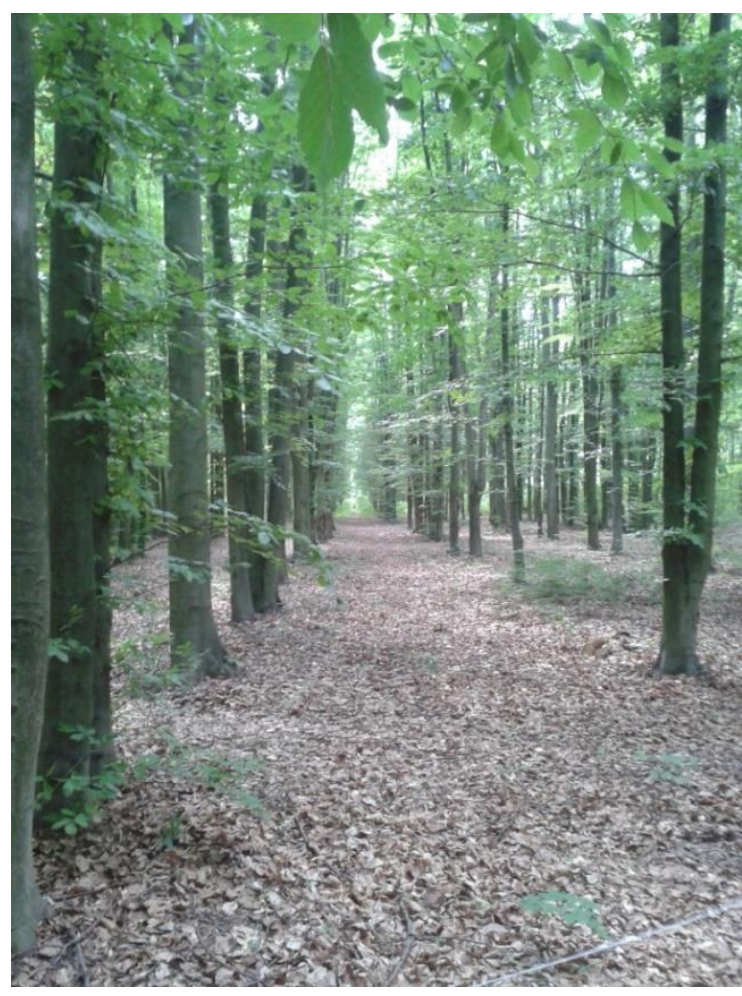

Рис. 4 - Насадження бука лісового на території дендропарку ДП «Тростянецьке ЛГ» (2017 р.) 


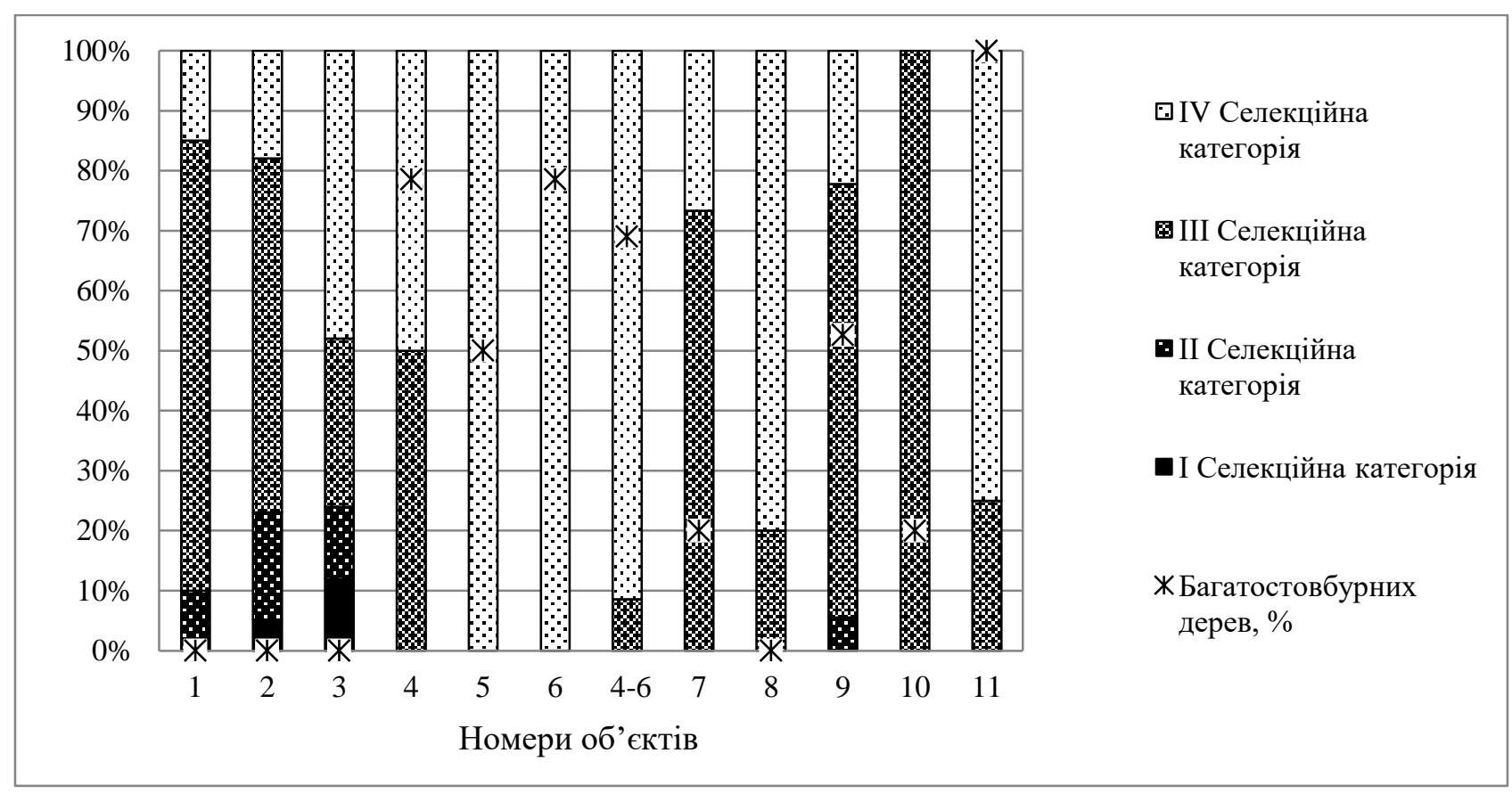

Рис. 5 - Якість стовбурів буків лісового, кримського та східного на обстежених об'єктах: 1 - бук лісовий (Тростянець, дослідні культури), 2 - бук лісовий (Тростянець, дослідні культури - дендропарк), 3 - бук кримський (Тростянець, дослідні культури - дендропарк), 4-6 - бук лісовий (Харківська ЛНДС, географічні культури), 7 - бук лісовий (Харківська ЛНДС, дендропарк), 8 - бук кримський (Харківська ЛНДС, дендропарк), 9 - бук лісовий (ХНАУ, дендропарк), 10 - бук східний (ХНАУ, дендропарк), 11 - бук лісовий (Балаклея, дендропарк)

Іншим важливим показником якості, який одночасно вказує на адаптованість рослин до нових умов, є частка багатостовбурних дерев. Висока частка таких дерев свідчить не лише про погану селекційну структуру, але й на погану адаптованість. Низька частка або відсутність таких дерев може вказувати, навпаки, не лише на добру якість, але й на добру адаптованість насадження. Відзначено відсутність або незначну частку таких дерев у ДП «Тростянецьке ЛГ» і для бука кримського - у дендропарку УкрНДІЛГА (див. рис. 5). Разом із тим, усі дерева в дендропарку ДП «Балаклійське ЛГ» мали по декілька стовбурів. Високу частку таких дерев (50-79\%) виявлено також у варіантах географічних культур у ДП «Харківська ЛНДС».

Як відомо (Lypa 1977), найважливішими для оцінювання успішності інтродукції є не інтенсивність росту, і навіть не стан рослин, а їхня спроможність до насіннєвого розмноження та відновлення в нових умовах. За нашими дослідженнями, у дослідних культурах і на ділянках бука лісового і кримського в дендропарках ДП «Тростянецьке ЛГ», УкрНДІЛГА та ХНАУ відбувається регулярне плодоношення та утворення самосіву (рис. 6). У дендропарку ДП «Тростянецьке ЛГ» поодиноко наявний благонадійний підріст бука лісового заввишки до 0,7 м і віком до 5 років. Більшість із обстежених насаджень оцінено 45 ступенем акліматизації за О. Л. Липою.

Аналіз кліматичних умов регіонів заготівлі насіння та розташування об'єктів свідчить, що район Мукачева вирізняється найвищими температурами (середньорічна $-+9,6^{\circ} \mathrm{C}$ ) $\mathrm{i}$ кількістю річних опадів (683 мм на рік). За близьких температурних режимів між Харковом і Тростянцем (середньорічна температура повітря $+7,4$ i $+7,5^{\circ} \mathrm{C}$ відповідно) існують відмінності в кількості річних опадів (528 і 630 мм). Район розташування м. Балаклея відрізняється вищими температурами (середньорічна $-+7,8^{\circ} \mathrm{C}$ ) та ще меншою річною кількістю опадів (508 мм). 

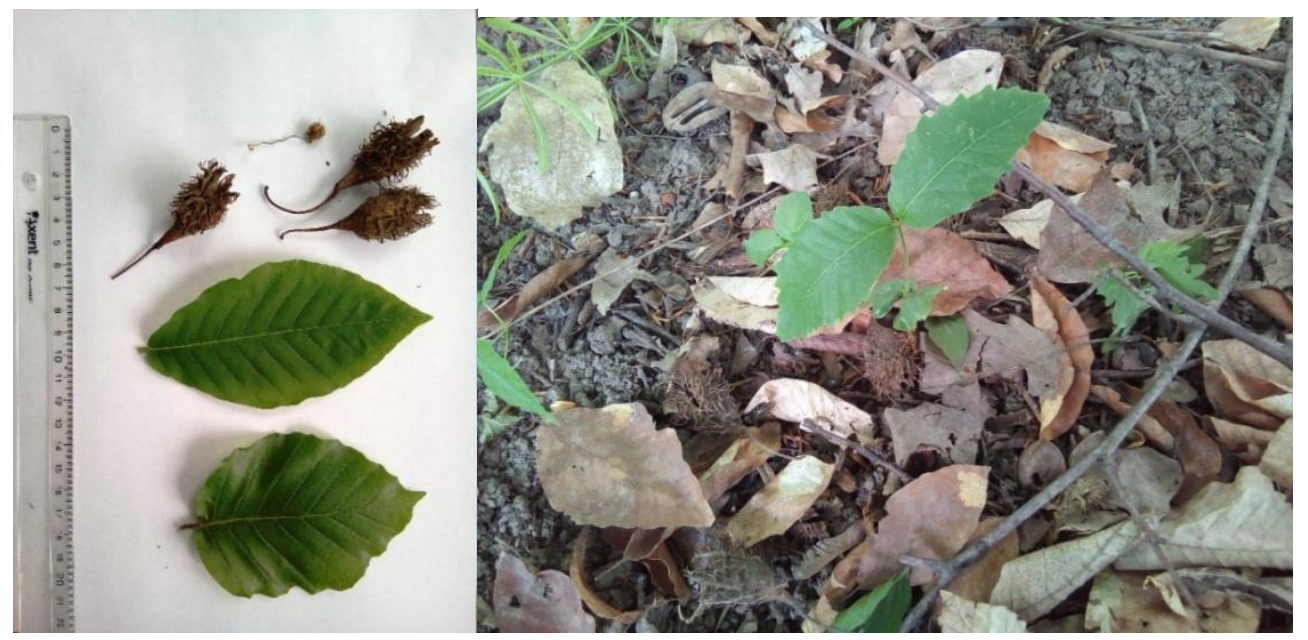

Рис. 6 - Плоди та самосів бука лісового в дендропарку УкрНДІЛГА (2019 р.)

Простежується певна подібність кліматограм для міст Мукачево та Тростянець (рис. 7), водночас для району розташування Тростянця характерні нижчі зимові температури. Аналіз кліматограм міст Харків і Балаклея та міста Мукачево свідчить про значну різницю за кількістю опадів, особливо впродовж вегетаційного періоду. У посушливі періоди влітку у районах міст Харків і Балаклея створюються несприятливі для росту бука екологічні умови, що й пояснює його повільний ріст і погану якість стовбурів. Для бука кримського побудувати такі кліматограми було неможливо через відсутність інформації щодо місць заготівлі його насіння.

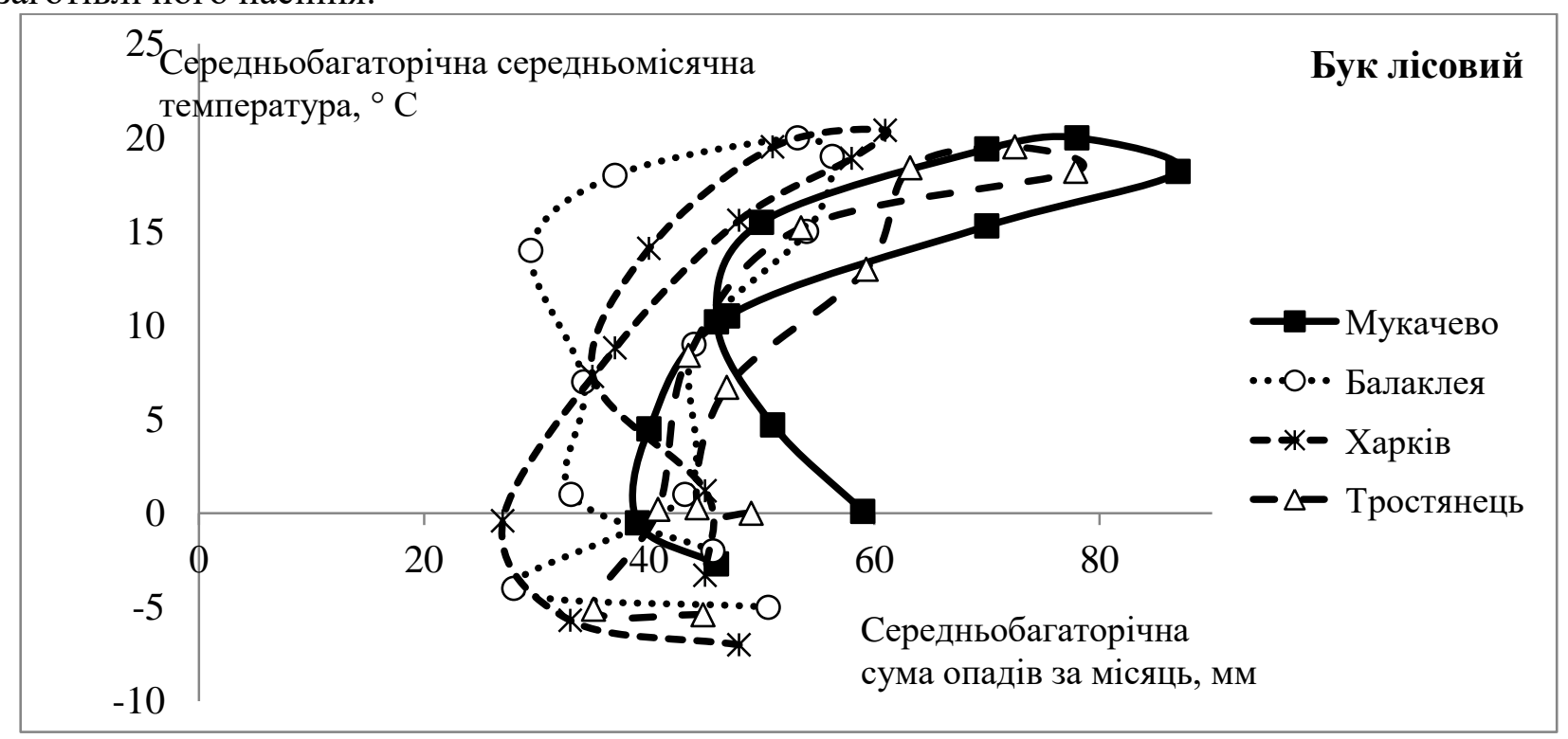

Рис. 7 - Порівняння кліматичних умов дослідних ділянок бука лісового та району заготівлі насіння за допомогою кліматограм Болла-Тейлора

Сумарний показник комплексного оцінювання дерев бука на 10 ділянках у дослідних культурах i дендропарках за 6 характеристиками становить 13-28 балів. Результати оцінювання лише двох насаджень бука лісового (дослідні культури та ділянка в дендропарку ДП «Тростянецьке ЛГ») свідчать про перспективність виду для використання в лісовому господарстві, а два варіанти в географічних культурах та група дерев у дендропарку ДП «Балаклійське ЛГ» визнані малоперспективними. У географічних культурах найкращими характеристиками вирізнявся бук рівнинного походження. Решту оцінено як умовно перспективні (рис. 8). Насадження бука кримського в дендропарку ДП «Тростянецьке ЛГ» та в дендропарку ДП «Харківська ЛНДС» оцінено в 22 бали, що також $є$ доволі високим показником. 


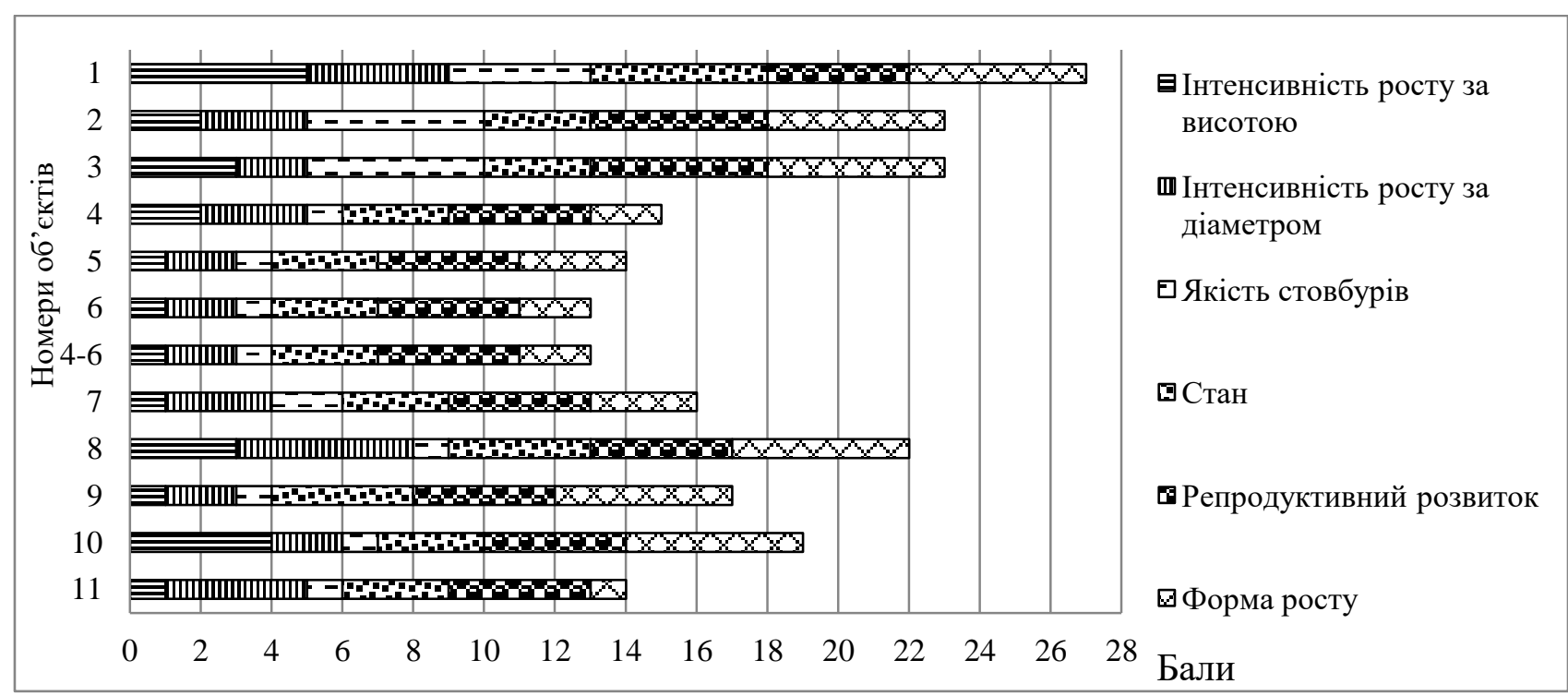

Рис. 8 - Комплексне оцінювання насаджень бука в Харківській та Сумській областях: 1 - бук лісовий (Тростянець, дослідні культури); 2 - бук лісовий (Тростянець, дослідні культури - дендропарк); 3 - бук кримський (Тростянець, дослідні культури - дендропарк); 4-6 - бук лісовий (Харківська ЛНДС, географічні культури); 7 - бук лісовий (Харківська ЛНДС, дендропарк); 8 - бук кримський (Харківська ЛНДС, дендропарк); 9 - бук лісовий (ХНАУ, дендропарк); 10 - бук східний (ХНАУ, дендропарк); 11 - бук лісовий (Балаклея, дендропарк)

Буки лісовий та кримський вирізняються високою декоративністю. Гарна гладка сіра кора, щільна крона насиченого зеленого кольору літом, жовтого з рудим відтінком восени виглядає дуже ефектно та може прикрасити парк або сквер. Проте спеціально декоративність зазначених насаджень ми не вивчали (рис. 9).

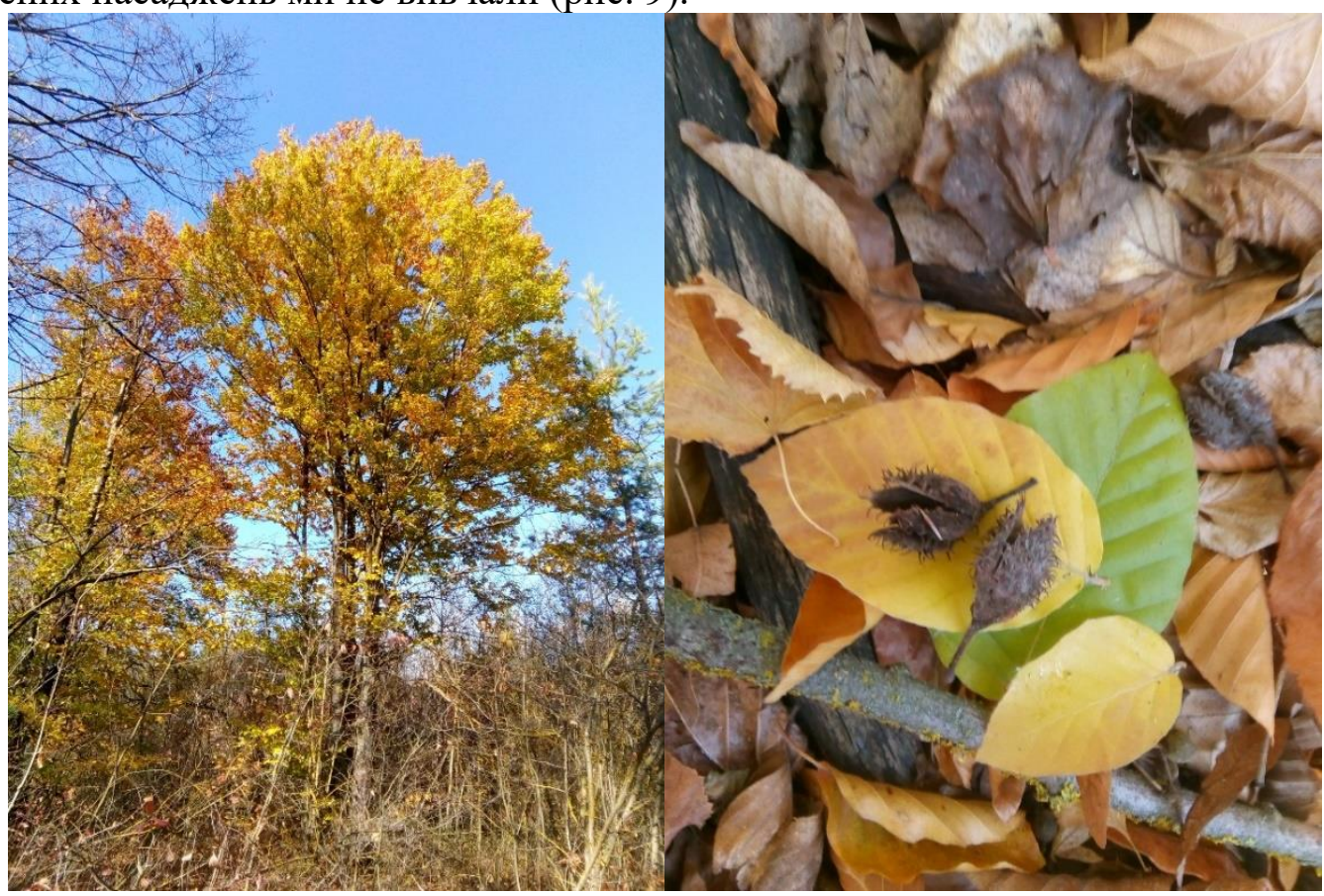

Рис. 9 - Бук лісовий у дендропарку ДП «Балаклійське ЛГ» (2019 р.)

Таким чином, за результатами комплексного оцінювання буки лісовий і кримський визнано перспективними для створення плантаційних культур лише в лісостеповій частині Сумської області, буки лісовий, східний i кримський доцільно використовувати для озеленення в Харківській і Сумській областях. 
Отримані результати свідчать не лише про високі адаптаційні можливості видів роду Fagus в умовах інтродукції, але й про їхню високу пластичність. Тому можемо припустити, що ці види здатні витримати збільшення континентальності клімату природних ареалів без значних втрат продуктивності, але ці питання потребують більш детального вивчення.

Висновки. Бук лісовий у дослідних культурах ДП «Тростянецьке ЛГ» на Сумщині за інтенсивністю росту перевершує різні види бука в інших обстежених об'єктах і дуб звичайний місцевого походження (за висотою - 13,5 \%, а за діаметром $-6,4 \%$ ).

Найкращою якістю стовбурів вирізняються насадження ДП «Тростянецьке ЛГ». Відсутність або незначну частку дерев бука лісового з декількома стовбурами відзначено у ДП «Тростянецьке ЛГ», а бука кримського - в дендропарку УкрНДІЛГА.

Наявність наявність самосіву, а у дендропарку ДП «Тростянецький лісгосп» поодинокого підросту бука лісового свідчить, що більшість обстежених насаджень характеризуються 4-5 ступенем акліматизації за О. Л. Липою.

Результати комплексного оцінювання дають змогу рекомендувати використання буків лісового і кримського для створення плантаційних культур у лісостеповій частині Сумської області, а також для озеленення в Харківській і Сумській областях.

\section{ПОСИЛАННЯ - REFERENCES}

Anuchin N. P. 1982. Forest mensuration. Moscow, Lesnaya promyshlennost, 552 p. (in Russian).

Asadulaev, Z. M., Ramazanova Z. R., Sadykova H. A. 2013. Comparative assessment of climatic diagrams and their modifications in the interpretation of botanical studies. Bulletin of the Dagestan Scientific Center [Vestnyk dahestanskoho nauchnoho tsentra], 50: 42-48 (in Russian).

Belous, V. Y. 1962. Beech plantations in the forest enterprises of Vinnitsa and Khmelnitsky Regions of the Ukrainian SSR]. Lesnoy Zhurnal [Russian Forestry Journal], 1: 32-33 (in Russian).

Ihnatenko, V. A., Cherniavskyi. M. V., Samodai V. P. 2006. Productivity of oak-beech stands in the Left-bank Forest Steppe and Transcarpathia. In: Gorgan Biodiversity Conservation and Reproduction, Nadvirna, 70-74 (in Ukrainian).

Grybovich, E., Khalimon, O., Los, S. 2018. Introduced trees in park-monument of landscape art in Poltava city. Formation of urban green areas. Past, present, fiture. Klaipeda State University of Applied Sciences, 1 (15): 126-134.

Kozlov, V. H. 1992. Introduction of beech (Fagus L.) species and forms in the Right-Bank of Forest-Steppe of Ukraine and the prospects for their use in the national economy. Extended abstract of $\mathrm{PhD}$ thesis. Kyiv, 20 p. (in Russian).

Kokhno, M. A. and Parkhomenko, L. I. 2002. Dendroflora of Ukraine. Wild and cultivated trees and shrubs. Angiosperms part I. Kyiv, Fitosotsiotsentr, 447 p. (in Ukrainian).

Korinko O. M. 2007. The beech crops growing within Ukraine. NAU Scientific Reports [Naukovi dopovidi NAU], 2 (7): 1-6 (in Ukrainian).

Los, S. A., Gritsaychuk, V. V., Chepiga, A. M. 2014. Specific features of growth and development of European beech in the climate of the North East of Ukraine]. Biology and valeology: Bulletin of Kharkiv National Pedagogical University, 16: 77-84 (in Ukrainian).

Los, S. A., Samodai V. P., Tereshchenko L. I. 2018. The beech perspectivity evaluation in the Left-Bank ForestSteppe of Ukraine conditions. In: Main problems and tendencies of further development of forestry in the Ukrainian Carpathians. Ivano-Frankivsk, NAIR, p. 357-362 (in Ukrainian).

Lypa, O. L. 1977. Dendrology with fundamentals of acclimatization. Kyiv, Vyshcha shkola, 222 p. (in Ukrainian).

Molotkov, P. Y. 1966. Beech forests and their management. Moscow, Lesnaya promyshlennost, 224 p. (in Russian).

Molotkov, P. Y. 1986. Experience of beech planting near Kharkov. Forestry and Forest Melioration, 70 : 33-35 (in Ukrainian).

Poplavskaya, G. I. 1927. Materials on the study of Crimean beech variability. Journal of Russian Botanical Society of the Academy of Sciences of the USSR, XII(1-2): 59-76 (in Russian).

Prots, B. H., Pokynchereda, V. F., Berkela, Y. Y. 2019. The result of the second stage of nomination of beech virgin and old-growth forests of Ukraine to the World Natural Heritage of UNESCO. Proceedings of the State Natural History Museum, 35: 89-96 (in Ukrainian).

Rumiankov, Yu. O. 2018. Monogardens of species and forms of beech (Fagus L.) in the national dendrological park "Sofiyivka" of the National academy of sciences of Ukraine. Scientific Bulletin of UNFU, 28(5): 44-48 (in Ukrainian). https://doi.org/10.15421/40280509

Shvidenko, A. Z., Strochinsky, A. A., Savich, Yu. N., Kashpor, S. N. (Eds.). 1987. Regulatory reference materials for forest inventory in Ukraine and Moldova. Kyiv, Urozhay, 560 p. (in Russian).

Stoyko, S. M. 2018. Ecology, coenotic heterogeneity of the forest beech formation in Ukraine and the protection of pristine ecosystems. Proceedings of the Forestry Academy of Sciences of Ukraine, 17: 149-157 (in Ukrainian). 


\section{ЛICIВНИЦТВО I АГРОЛІСОМЕЛІОРАЦIЯ - FORESTRY AND FOREST МЕLIORATION}

2020. Вй. 136 - 2020. Iss. 136

Sytnyk, I. I. 2017. Parks of Kharkiv National Agrarian University named after VV Dokuchaev. 2nd edition. Kharkiv, 225 p. (in Ukrainian).

Volosyanchuk, R. T., Los, S. A., Torosova, L. O., Kuznecova T., Tereshchenko L., Neyko I. \& Grygoryeva, V. G. 2003. Methodological approaches to the estimation of gene pool conservation in situ units of the broadleaves tree species and their actual conditions in the Left-bank forest steppe of Ukraine. Forestry and Forest Melioration [Lisivnytstvo i ahrolisomelioratsiya], 104: 50-57 (in Ukrainian).

Voron, V. P., Lavrov, V.V., Orlovskyi, V. K. 1996. Resistance of wood and shrub species to agro-technogenic pollution by emissions of Balaklia Cement Plant. Forestry and Forest Melioration [Lisivnytstvo i ahrolisomelioratsiya], 92: 22-26 (in Ukrainian).

Wysotska, N. Yu. 2013. Methodology of complex evaluation of Picea Dietr. species introduction success. Forestry and Forest Melioration [Lisivnytstvo i ahrolisomelioratsiya], 122: 56-62 (in Ukrainian).

Zaiachuk, V. I. 2014. Dendrology. Second edition with changes and additions. Lviv, Spolom, 676 p. (in Ukrainian).

Los S. A. ${ }^{1}$, Samoday V. P. ${ }^{2}$, Tereshchenko L. I. ${ }^{1}$, Birchenko D. Ye. ${ }^{3}$

CURRENT STATE OF BEECH IN THE EXPERIMENTAL PLANTATIONS AND ARBORETUMS IN NORTHEASTERN UKRAINE AND PROSPECTS OF ITS USE

${ }^{1}$ Ukrainian Research Institute of Forestry and Forest Melioration named after G. M. Vysotsky

${ }^{2}$ Krasnotrostyanetske Branch of Ukrainian Research Institute of Forestry and Forest Melioration named after G. M. Vysotsky

${ }^{3}$ Kharkiv State Zooveterinary Academy

The article summarises findings concerning the European beech (Fagus sylvatica L.), Eastern beech (Fagus orientalis Lypsky.) and Crimean beech (Fagus taurica Popl.) obtained in experimental plantations and arboretums in North-Eastern Ukraine. The aim of the research was to determine whether the species can be used when creating forest stands of various purposes in the region. Eleven beech stands were assessed according to a set of indicators which included growth characteristics, stem quality, condition and reproductive development. According to the results of a comprehensive assessment, European and Crimean beeches have been recognized as promising for the creation of stands. Furthermore, European, Eastern and Crimean beeches should be used for landscaping in Kharkiv and Sumy Regions.

K e y words: Fagus, complex assessment, multitrunk, selection category, reproduction,.

Лось С. А. ${ }^{1}$, Самодай В. П. ${ }^{2}$, Терещенко Л. И. ${ }^{1}$, Бирченко Д. Е. ${ }^{3}$

СОВРЕМЕННОЕ СОСТОЯНИЕ БУКА В ОПЫТНЫХ КУЛЬТУРАХ И ДЕНДРОПАРКАХ СЕВЕРОВОСТОКА УКРАИНЫ И ПЕРСПЕКТИВЫ ЕГО ИСПОЛЬЗОВАНИЯ

${ }^{I}$ Украинський научно-исследовательский институт лесного хозяйства и агролесомелиорации им. Г. Н. Высоикого

${ }^{2}$ Краснотростянеикое отделение Украинского научно-исследовательского института лесного хозяйства и агролесомелиорачии им. Г. Н. Высоикого

${ }^{3}$ Харьковская государственная зооветеринарная академия

Представлены обобщенные результаты обследований насаждений бука лесного (Fagus sylvatica L.), бука восточного (Fagus orientalis Lypsky.) и бука крымского (Fagus taurica Popl.) в опытных культурах и дендрологических парках северо-востока Украины. Целью исследований было определение пригодности видов для создания насаждений различного целевого назначения в регионе. Оценены 11 насаждений бука по комплексу показателей, в частности, по особенностям роста, качеству стволов, состоянию и репродуктивному развитию. По результатам комплексной оценки буки лесной и крымский признаны перспективными для создания плантационных культур. Буки лесной, восточный и крымский целесообразно использовать также для озеленения в Харьковской и Сумской областях.

Ключевы е слова : Fagus, комплексная оценка, многоствольность, селекционная категория, репродукция.

E-mail:svitlana_los@ukr.net

Одержано редколегією 07.05.2020 